\title{
Impacts on perspective of death in relatives of pediatric oncology patients: a systematic review

\begin{abstract}
Hellen Lúcia Cruz Caldas Lins ${ }^{1}$, Larissa Souza da Cruz² , Cláudio Couto Lóssio Neto², Paula Pessoa Pinheiro², Jucier Gonçalves Júnior ${ }^{2}$, Maria do Socorro Martins Cardoso Novais ${ }^{1}$, Kécia Silva Damasceno1,2, Vânia Barbosa do Nascimento1, Modesto Leite Rolim Neto²
\end{abstract}

\section{Abstract}

Background: The impacts of the news of a child/adolescent with cancer are devastating for the patient and his family. This study highlights - through a systematic literature review - the main consequences on the pediatric oncology patient's family, while facing the cancer situation.

Methods and Findings: Systematic literature review in BVS (Biblioteca Virtual em Saúde) and SciELO (Scientific Eletronic Library Online) from original studies published from January 15t, 2008 to November 30th, 2012 and that report the trajectories of illness and/ or disease course of pediatric oncology patients in the family perspective. The following keywords were chosen as elegibility criteria on the search: "child"[MesH]; "cancer" [Keyword]; "Family" [MeSH] and "death" [MesH]. Of the 569 manuscripts found, 22 met all these eligibility criteria. Studies have shown that the difficulties begin when the cancer is diagnosed. The acceptance of the diagnosis by the family, the overspending expenses, stress, fear and anxiety are examples of emotional overloads which caregivers are exposed. It is noticed that the caregiver job is performed by the mother, while the father is responsible for the "economic mainstay". On this context, the intimate relation with faith arises or intensifies, in the form of acceptance or denial.

Conclusion: The cancer treatment in children should not be focused only on the patient but also on the family - the essential indicator for attenuation on patients suffering
1 Health Sciences Postgraduate Program, ABC Region Medical School, Santo André, São Paulo, Brazil.

2 Departament Medicine, Federal University of Cariri, Barbalha, Ceará, Brazil.

\section{Contact information:}

Jucier Gonçalves Júnior.

Tel: (055) (88)99176746

Address: 284, Divine Savior Street, Downtown, Barbalha, Ceará, Brazil, 63180000

” juciergjunior@hotmail.com

\section{Keywords}

Children, death, families, neoplasms 


\section{Introduction}

Childhood cancer is the name of a cohort of noncontagious diseases that affect children and adolescents from 0 to 19 years who has in common the appearance of modified cells that multiply fast and disorderly in some parts of the body, damaging its function [1]. The estimated number of cancer cases in the U.S. for the year 2012 was 1.638.910, of which was estimated that 577.190 were fatal (more than 1500 deaths a day) [2].

Literature evidences that the most common pediatric tumors are leukemia [3], lymphoma, and tumor of the central nervous system [4]. Cancer is the second major cause of death in children from 1 to 14 years in the U.S., second only to accidents [2]. It was estimated for Brazil, in 2014, 394,450 cases of cancer, except non-melanoma skin tumors. As the median percentage of pediatric tumors is close to $3 \%$, therefore it appears that there are approximately 11,840 cases of cancer in children and adolescents up to 19 years. The Southeast and Northeast regions present largest number of cases, 5,600 and 2,790, respectively, followed by the South $(1,350$ new cases), Midwest (1,280 new cases) and North (820 new cases) [5].

Childhood cancer usually presents in unexpectedly, giving to the parents few opportunities to prepare for the demands of caring for their child newly diagnosed [6]. In psychosocial and cultural context, cancer is still considered as a curse, death sentence, a bad omen, and not a simply disease [7]. Among the childhood's chronic diseases, cancer stands out for high incidence and impact on the lives of children and their families accounting for changes of roles in family dynamics that covers economic and psychological distress in any household [1].

The present study was based on the following guiding question: what practical contributions to the scientific literature produced in the period of 2008-2012, has to offer feedback about the impacts of death in pediatric oncology patients about the family trajectories? This review highlights the pro- cess of death/dying of children with cancer and their influence on family dynamics as a fundamental dimension to be considered in palliative care of these patients. Thus, our objective was to evaluate the current evidence concerning to different perspectives (Emotional, Economic and Psychossocial) of impacts of the process of death/dying child with cancer in their families, formulating a systematic review. Our hypothesis is that, despite the growing interest toward the theme, human resources (ie, healthcare team in general) are not yet adequately trained to address impacts from death perspective in relatives of pediatric oncology patients, thus meriting greater theoretical contributions subsidized by qualitative multicenter studies as well as research of recognized statistical support as meta-analysis.

\section{Methods}

The research form was used by capturing data in electronic databases: SciELO and Biblioteca Virtual em Saúde (BVS). It was delimited that the search period would be from January $1^{\text {st }}, 2008$ to November $30^{\text {th }}, 2012$. The reason to delimit the search for the period 2008-2012, was the lack of studies that focused on the impacts of death in pediatric oncology patients and through the family trajectories. The search was carried using the following terms:

\#1."child" [Medical Subject Headings [MeSH];

\#2. "cancer" [Keyword];

\#3. "Family" [MeSH];

\#4. "death"[MesH].

Complementing the research, the use of the keyword "cancer" is justified because this term, though not cataloged in $\mathrm{MeSH}$, is often used to characterize studies dealing with the issue the subject of this review. The selection of data was made during the month of December 2012. The articles identified by the strategy of initial search were independently reviewed by the authors, according to the following inclusion criteria: (1) Manuscripts that report the trajectories of illness and/or disease course of pedia- 
tric oncology patients in the family perspective; (2) Original studies with full text accessible via Portal of Journals of the CAPES (Coordenação de Aperfeiçoamento Pessoal de Nível Superior), a virtual library created by the Brazilian Ministry of Health and that has restricted content to authorized users; and (3) manuscripts written in English and/or Portuguese. They were excluded: (1) non-original studies such as editorials, comments, and letters to the editor (2) studies and case report, books, monographs, case series, corrections/erratum and literature reviews. Manuscripts that present repeated information or available in other articles were also excluded.

Regarding the search strategy, it occurred in three phases. The first phase occurred in VHL. In this first stage we use the following strategy: \#1 AND \#2 AND \#3, yielding 491 articles of which 12 were selected. The second stage we use \#1 AND \#2 AND \#3 AND \#4 yielding 68 articles of which 7 were selected. The third stage occurred in ScIELO. In the third phase the descriptors used \#1 AND \#2, yielding 10 items of which 2 were selected. Subsequently, each selected article was read entirely, and important data from this review was organized on a spreadsheet containing: authors, year of publication, sample, journals and main presented data (PICOS). The data were extracted independently by two researchers, and the differences analyzed by a senior researcher in the area.

In order to enhance the data analysis, the next stage involved the group of the results on four themes for heuristic reasons: "Feelings of the families of pediatric cancer patients"; "Problems faced by parents of pediatric cancer patients"; "Coping mechanisms used by parents of pediatric cancer patients" and "Interventions in relatives of pediatric oncology patients".

In an attempt to decrease the risk of bias for this review, we only considered studies with evidence level A or B according to the Oxford Centre rating for Evidence-Based Medicine. Some studies reported the biopsychosocial condition of pediatric oncology patients' family/caregivers, followed by other topics. These were not compiled/tabulated because they did not agree with the selected main theme in this research.

This was a literature review, therefore there was no involvement in recruitment of patients. In this sense, ethical approval was not necessary. This revision is using the PRISMA protocol (http://www. prisma-statement.org/).

According to the adopted strategy, 438 manuscripts were found initially. The manuscripts that appeared more than once in the mentioned database were tallied in count only once. After analyzing the specific inclusion criteria emphasizing the authors, year of publication, methodological design, number of subjects $(N)$, comparison groups, and main results of the cited articles, we obtained a total of 21 selected and included manuscripts (Figure 1). The selected articles were derived from SciELO and BVS. Table 1 presents the results of a systematic review of the manuscripts included in the final sample (PI$\cos )$.

Table 1. Impacts from death perspective in relatives of pediatric oncology patients a systematic review. Study Particularities (PICOS).

\begin{tabular}{|c|c|c|c|}
$\begin{array}{c}\text { Author } \\
\text { (Year) }\end{array}$ & Journal & \multicolumn{1}{|c|}{ Sample } & \multicolumn{1}{c|}{ Study Particularities } \\
\hline $\begin{array}{c}\text { Sampaio, } \\
(2011)[8]\end{array}$ & $\begin{array}{l}\text { Psicol. } \\
\text { Argum }\end{array}$ & $\begin{array}{l}58 \text { caregivers of a } \\
\text { total of } 147 \text { holdings } \\
\text { of a support group for } \\
\text { families of children with } \\
\text { cancer }\end{array}$ & $\begin{array}{l}12 \text { meetings in which parents had the opportunity to discuss } \\
\text { topics related to their situation: to have a child with cancer, } \\
\text { their doubts, fears and dilemmas. All supervised by a trained } \\
\text { professional. }\end{array}$ \\
\hline
\end{tabular}




\begin{tabular}{|c|c|c|c|}
\hline $\begin{array}{l}\text { Angelo } \\
(2010)[9]\end{array}$ & Mundo Saúde & $\begin{array}{l}10 \text { families of children with } \\
\text { cancer }\end{array}$ & $\begin{array}{l}\text { The analysis of the narratives allowed to connect the stories by } \\
\text { the similarity: } \\
\text { a) the suffering in cancer situation is an intense personal } \\
\text { experience, based on universal meanings, as well as cultural, } \\
\text { family and personal. } \\
\text { b) the suffering in cancer puts families in life limit, creating the } \\
\text { necessity to relate to the Divine. } \\
\text { c) spirituality is present in the way that family perceives the } \\
\text { meaning of events. } \\
\text { d) spiritual practices are related to the search for the meaning of } \\
\text { suffering and find answers to existential questions of cancer } \\
\text { in family life. } \\
\text { e) the suffering generates in the family the necessity to show } \\
\text { and legitimate pain experienced, through narrative. }\end{array}$ \\
\hline $\begin{array}{l}\text { Castro } \\
(2010)[10]\end{array}$ & $\begin{array}{l}\text { Rev. Mal-Estar } \\
\text { Subj. }\end{array}$ & $\begin{array}{l}15 \text { mothers hosted at } \\
\text { Lar de Apoio à Criança } \\
\text { com Câncer Manaus- } \\
\text { Amazonas/Brasil }\end{array}$ & $\begin{array}{l}\text { Several changes occur in the lives of mothers: exit of the } \\
\text { home and the consequent remoteness of the other children, } \\
\text { unstructured of marriage, fear of death, itinerancy that } \\
\text { treatment of children often requires. }\end{array}$ \\
\hline $\begin{array}{l}\text { Deh, Collier } \\
\text { and Hall } \\
\text { (2012)[11] }\end{array}$ & $\begin{array}{l}\text { Health Qual } \\
\text { Life Outcomes }\end{array}$ & $\begin{array}{l}300 \text { Jordanians couples } \\
\text { who have children with } \\
\text { cancer compared with } 558 \\
\text { couples Jordanians who } \\
\text { do not have children with } \\
\text { cancer. }\end{array}$ & $\begin{array}{l}\text { The level of stress in mothers who have children with cancer } \\
\text { is much higher than those mothers whose children have no } \\
\text { serious illness. However, having a child with cancer did not } \\
\text { show significant association with the level of stress reported by } \\
\text { parents. }\end{array}$ \\
\hline $\begin{array}{l}\text { Duarte, } \\
\text { Zannini and } \\
\text { Nedel (2012) } \\
\quad[12]\end{array}$ & $\begin{array}{l}\text { Revista } \\
\text { Gaúcha de } \\
\text { Enfermagem }\end{array}$ & $\begin{array}{l}13 \text { family responsible for } \\
\text { the care of children in } \\
\text { the general hospital of } \\
\text { Rio Grande do Sul, Unit } \\
\text { oncology and pediatric } \\
\text { hematology }\end{array}$ & $\begin{array}{l}\text { There are significant changes in family life; Main feelings } \\
\text { experienced by parents: fear, depression and guilt, difficulties } \\
\text { and strategies used in the treatment, recurrences to spirituality is } \\
\text { common. }\end{array}$ \\
\hline $\begin{array}{l}\text { Eiser, Eiser } \\
\text { Jr and Stride } \\
(2005)[13]\end{array}$ & $\begin{array}{l}\text { Health Qual } \\
\text { Life Outcomes }\end{array}$ & $\begin{array}{l}87 \text { families of children } \\
\text { with Acute Lymphoblastic } \\
\text { Leukemia (ALL) }\end{array}$ & $\begin{array}{l}\text { The mothers reported lower levels of quality of life as well as } \\
\text { their children compared to the general population. Significant } \\
\text { correlation among the level of concern and quality of children } \\
\text { life (QOL). }\end{array}$ \\
\hline $\begin{array}{l}\text { Han, Cho } \\
\text { and Kim } \\
(2009)[6]\end{array}$ & $\begin{array}{l}\text { Psycho } \\
\text { Oncology }\end{array}$ & $\begin{array}{l}200 \text { Korean mothers of } \\
\text { children with cancer }\end{array}$ & $\begin{array}{l}\text { Facing strategies of Korean mothers are evidenced through } \\
\text { the optimistic outlook, trying to preserve family integrity; } \\
\text { seeking information. These strategies were associated with less } \\
\text { psychological suffering and better family relationships. }\end{array}$ \\
\hline $\begin{array}{l}\text { Kazak et al } \\
(2005)[14]\end{array}$ & J Clin Oncol & $\begin{array}{l}119 \text { mothers of } 52 \text { fathers } \\
\text { of children on cancer } \\
\text { treatment }\end{array}$ & $\begin{array}{l}\text { Except one father, all other reported Posttraumatic Stress } \\
\text { Symptoms (PTSS). Moderate levels of PTSS for mothers and } \\
\text { fathers in general. In families with two parents participants, } \\
\text { almost } 80 \% \text { of cases have at least one parent with moderate to } \\
\text { severe PTSS. There was minimum association among PTSS and } \\
\text { elapsed time of diagnosis. }\end{array}$ \\
\hline
\end{tabular}


Kolsdhorf and

Costa Jr.

(2011)[3]
Estud. psicol.

30 caregivers of pediatric oncology patients

Kolsdhorf, and Costa Jr (2010)[15]
Interação em Psicol
30 caregivers of children and adolescents with Leukemia of Hospital de Base do Distrito Federal (HBDF)
Necessity for more attention, monitoring of the patient and increase of financial expenses. There were reports about learning new behavior patterns referred as favorable: acquisition of more adaptive behavior to environmental demands; perception of bigger auto-effectiveness and more active performance in the treatment; learning about invasive medical procedures destitution of dysfunctional beliefs associates to cancer.

The parental educative activities, in the first months of treatment, were characterized by: bigger permissively; secondary gains and super protection. However caregivers indicated the gradual acquisition of skills to deal with doctorinvasive procedures and collateral effect of the anti-neoplastic medication, throughout the treatment. There were changes in the familiar dynamics and reverberations in the daily professional.

Three thematic units had been identified: caregivers ahead of the diagnosis; caregivers in search of an explanation for the illness and caregivers trying to face the illness. Family searches different strategies of confrontation to the experience to have a child with cancer from the biomedical concept, psychosocial and of the faith.

Families surprised at cancer diagnosis had considerable expenses since diagnostic: treatment, cares in the accompaniment of the phases of the illness. Four great themes emerged in the research: necessity to work; income reduction; expenditures that the treatment brings more; incapacity to fit in assistance programs to complement or to substitute the lost income. It is observed that many of the decisions, as who will be the primary caregiver, are defined by the sex; in this case, the mother is who assumes this role, having that to reduce workload or to abandon the job.

The role of mothers was constructed by interaction of two process: "Living the time of the illness" - mothers concentrate on themselves, being permeated by the uncertainties inherent to the disease and the necessity to remove the threats to the life of their son; " Living a time of fight for the life of the child " which represents the dimension of the maternal behavior in this its new task: to take care of the child with cancer.

The parents remember the itineraries of the progression of the illness until the diagnosis. The word Leukemia was associated with the cancer and the death. Delay of the definitive diagnosis was attributed to difficulties with the listening of the symptoms; clinical particularities of the Leukemia; referral in the health system. The parents detached peregrinations for diverse places, loss of solvability, unnecessary expenses, emotional weariness and delay in the actions of health. 
Oliveira,

Costa and

Nóbrega

(2006)[19]

Oliveira et. al. (2010)[4]

Panganiban-

Corales and

Medina Jr,

(2011)[20]

Patiño-

Fernadez et

al. (2008)

[21]

\section{Pediatr. Blood Cancer}

Science, Care and Health

Asia Pac Fam Med

90 Philippine families who have a child with cancer.

mothers of children under twelve years of age carrier from some sort of cancer in chemotherapy treatment at Unidade de Pediatria da Associação de Combate ao Câncer em Goiás - Hospital Araújo Jorge

Six mothers who followed in the pediatrics unit of a hospital.

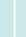

129 mothers and 72 fathers of children diagnosed with cancer contemporarily to the research

Pritctard et.

al. (2009)

[22]

J. Pain Symptom Manage

49 children's parents with cancer that were near to the end of the life.

Quintana et. Psicol. Argum al. (2011)[23]

Rajajee s,

Ezhilarasi and

Indumathi

(2007)[24]

Silva et. al. (2009)[1]

\section{Indian J}

Pediatr

Esc. Anna
Nery
Parents, caregivers, children and adolescents companions during the hospitalization in a public hospital.

\section{4 parents of children with} cancer, 19 were nuclear families and 15 families common.

Families of children and adolescents diagnosed with cancer more than two months ago, treated at Hospital Infantil Nossa Senhora da Glória (HINSG)
The established dialogue among the mothers with the nurses enabled the development of cares that had resulted in wellbeing of the relation with the children.

The ambiguity concerning the meanings of the chemotherapy and the difficulties ahead of the changes in the familiar dynamics was observed in the speeches of the mothers imposed by the treatment of the son. The fear, the uncertainties of the course of the illness, as well as the fear of the death is enough evident. The necessity of removal of the other children intensified the feelings of anguish and guilt in relation to the possibilities of these women about to be mother.

Most of the interviewed familiar indicates as form of adequacy to the treatment: faith and religion. Familiar resources and familiar function were correlated using Family APGAR Don't have correlation among pressure on caregivers and familiar function as well as of that one with familiar resources.

Descriptive statisticians and multiple linear regressions had been used to examine predictors of symptoms of acute stress (SAS). $51 \%(N=66)$ of mothers and $40 \%(N=29)$ of fathers found signals in the DSM-IV (Diagnostic and Statistics manual, $4^{\circ} \mathrm{d}$.) that were diagnostic criteria for ASD (acute stress disorder). Most of the sample told to have at least one SAS. General anxiety, but not functioning of the family, was a great predictor of SAS in both the mothers and the parents, at least after controlling demographic characteristics.

The parents knew that the end of the life of their children was near and described when the death of their children could happen of three forms: beforehand, by surprise, and delayed in relation their expectations. These categories differ slightly for standards of symptoms.

The mother's function is to keep and to assure the familiar cohesion and the integrity psychic and physical of the children. The responsibility for such integrity, by the illness situation, seems to generate intense load of suffering in the mother.

Family support is very important for treatment. Psychological and social impacts are highlighted to mothers. Group therapy was useful for sharing / treats possible injuries underscores to the treatment of children with cancer.

$20 \%$ of families experienced despair; $21 \%$, fear of death, $39 \%$ solidarity; $22 \%$, jealousy, 19\%, contempt, 56\% experienced changes in routines. The impacts involve physical, psychosocial and financial, causing transformations and generating imbalance in social and family life. 
Figure 1: Flow charts syntesizing the procedure for seleciion of studies for review. From: Mother D, Liberati A, Tetzlaff J, Altman DG, The PRISMA Group (2009). Preferred Reporting/temsforSystematic Reviews an Meta-Analyses: The PRISMA Statemente. PloS Med 6(6): e1000097.doi:10.137/journal.pmed1000097 For more information, visit www.prisma-statement.org.

\section{grasme PRISMA 2009 Flow Diagram}

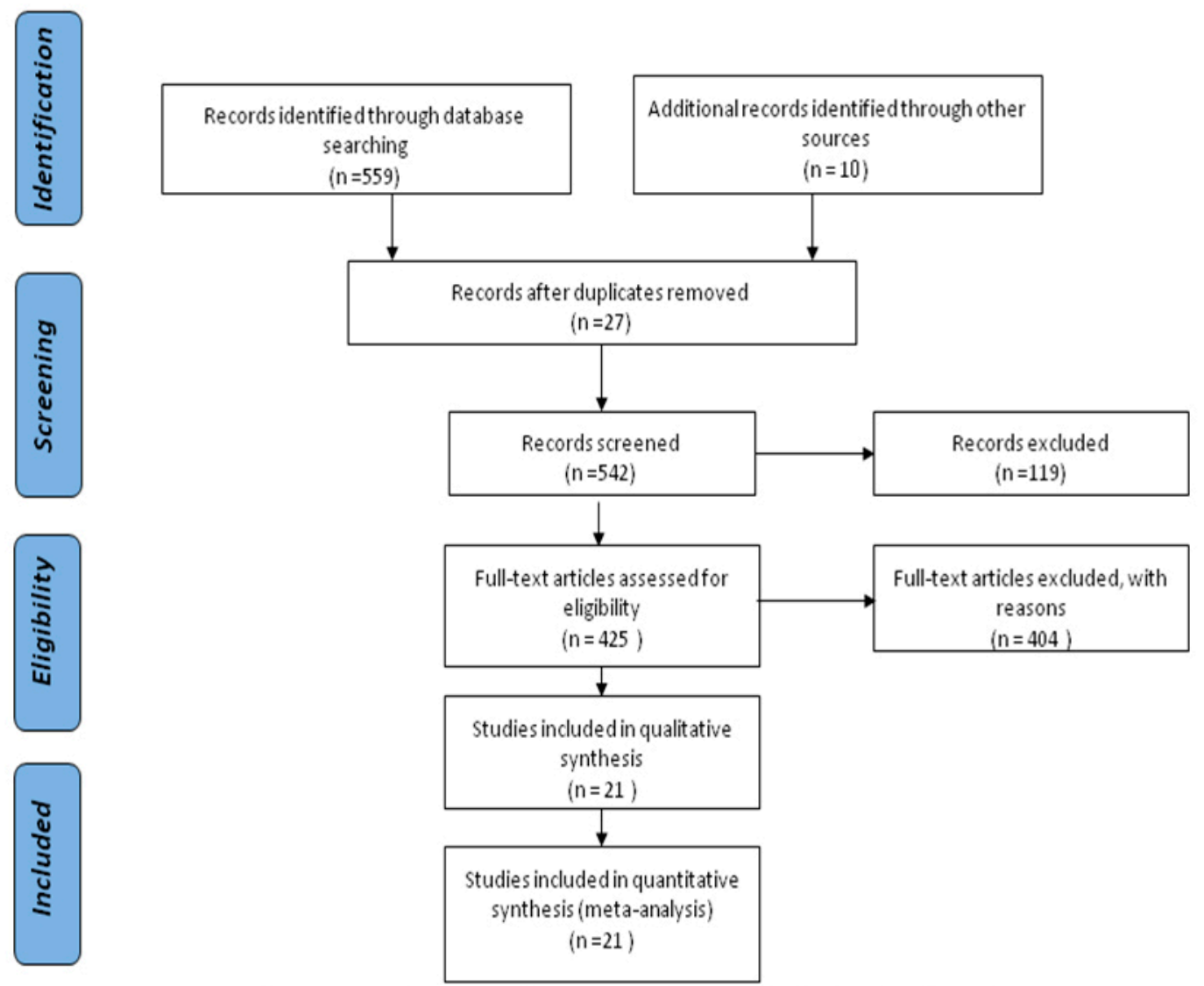

\section{Discussion}

Feelings of the families of pediatric cancer patients It is consensus among the researchers the importance of the knowledge about the illness by the family [16]. Thus, it was observed that the acceptance by the family of the situations imposed by the treatment is the first great difficulty after the diagnosis [19]. The feelings that family members experience after cancer diagnosis announcement and even in the pre-diagnostic step, relate to what is pointed out in the literature as a process of antici- patory grief [23]. In addition, fear, anguish, anxiety and stress were also listed as often [21] associated with the disease treatment routine [23].

The fear of children death; the uncertainty of healing; despair; helplessness; physical, mental and emotional fatigue permeated by hope are crucial for the development of anxiety and stress crises.

It is important to stand out the discrepancy among the stress levels associates to the context of the illness. In families with or without a child with cancer, mothers reported higher stress levels than 
fathers [11]. Moreover, mothers tend to be more involved with the care of the sick child, more responsible for medication and treatment decisions, and more likely to stay in hospital with the child. In contrast, fathers tend to work as much as possible and generally try to maintain normal family life for other children in the family $[13,15]$. Therefore, the main caregiver is the mother, while the father takes the responsibility of making up any economic necessities $[19,23]$. There is a manuscript that reports the different strategies of Korean mothers to deal with this situation [6].

"To be mother of a child with cancer," is experiencing abrupt changes in many ways of existence [10]. Moreira and Angelo [18] bring three stages of the trajectory of mothers on taking care of their children: 1) doubts - uncertainty about the cure of children, unawareness of medical procedures, uncertainty about how to act, 2) Acceptance the disease, the situation, 3) move forward - seek information about cancer with both doctors and others who passed through similar situations or still pass.

Siblings of the cancer child were also affected both by way of behavior problems and school performance [24].

There were reports in the review regarding family disintegration. It should be noted the perspective of imminent death intervening excessively on the couple relationship of the parents reflecting on the interaction between the child with cancer and the other brothers [1]. However, depending on the affective and emotional interactions interchanged to the illness, it can be an indicator of greater proximity and familiar cohesion [15].

\section{Problems faced by parents of pediatric cancer patients}

After initializing the treatment, the first major impact highlighted was the displacement from home to the hospital - facing a new regimented routine [19] with specific technical language [23] - in addi- tion to financial problems $[3,10,12]$ and unnecessary expenses [7].

Miedema et. al. [17] enumerates frequent travel expenses, accommodation and food for long periods. Caregivers often have to reduce their work hours or even leave their jobs (situation more observed in mothers), and even when they remain in employment at fully hours, there are difficulties on the part of caregivers to comply the workload, cost of medication, hospitalization, other medical procedures. Most researches note that even when there is access to public health services, the availability of these resources is incipient [20]. Besides highlighting the difficulties of families which take care of children with cancer to sign up on government programs to receive assistance [17].

The difficulty in obtaining government assistance is element that impose more complications to the situation that is complex. Inadequate access to medical care are also cited [20]. Others reported problems are disturbed sleep and difficulty in relating to people of hospital [19]. On this context immediately following their child's diagnosis of cancer, most mothers (51\%) and fathers (40\%) experience subclinical symptoms of acute stress (SAS) [21]. The stress levels of parents tend to exacerbate and then develop Posttraumatic Stress Symptoms (PTSS) [14, 17] (Figure 2).

Studies show the hardness in the diagnosis of childhood cancer. This impasse is, in part, due to the similarity of signs and symptoms of this disease with others [7]. This makes the disease process even more painful.

\section{Coping mechanisms used by parents of pediatric cancer patients}

Generally the articles argue about confrontation forms: faith, religion/spirituality, support of other families in the same situation, intra-family and health professional support [8-10, 12, 16, 20]. It is important to point out that some manuscripts presented more than one of the listed categories as axle of 
Figure 2: Promoters factors increase stress/suffering in parentes of the childrens with cancer.

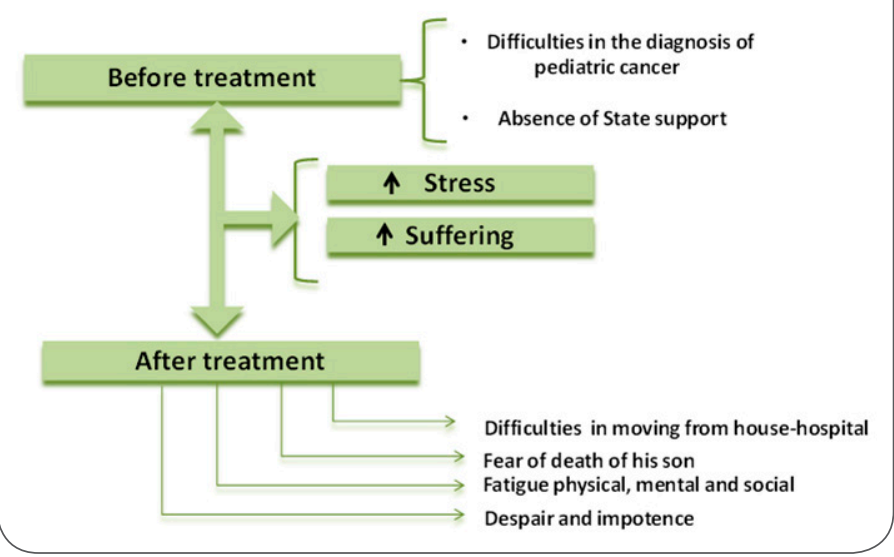

boarding, that shows the importance of these aspects and the intrinsic relation that exists among them.

Studies have emphasized that one of the family forms to face the perspective of death is by faith and religion. Thus, spiritual practices are related to the search for meaning of suffering and to find answers to existential questions of cancer in family life [9].

Faith, for families, has an important role in emotional balance and acceptance of the disease, providing strength to continue fighting [12]. Others mainstay family would be the solidarity of other families in the same situation $[8,10,12]$ intra-family support [23], the comfort of the health professional by clarifying on the various aspects of the disease [16] (Figure 3).

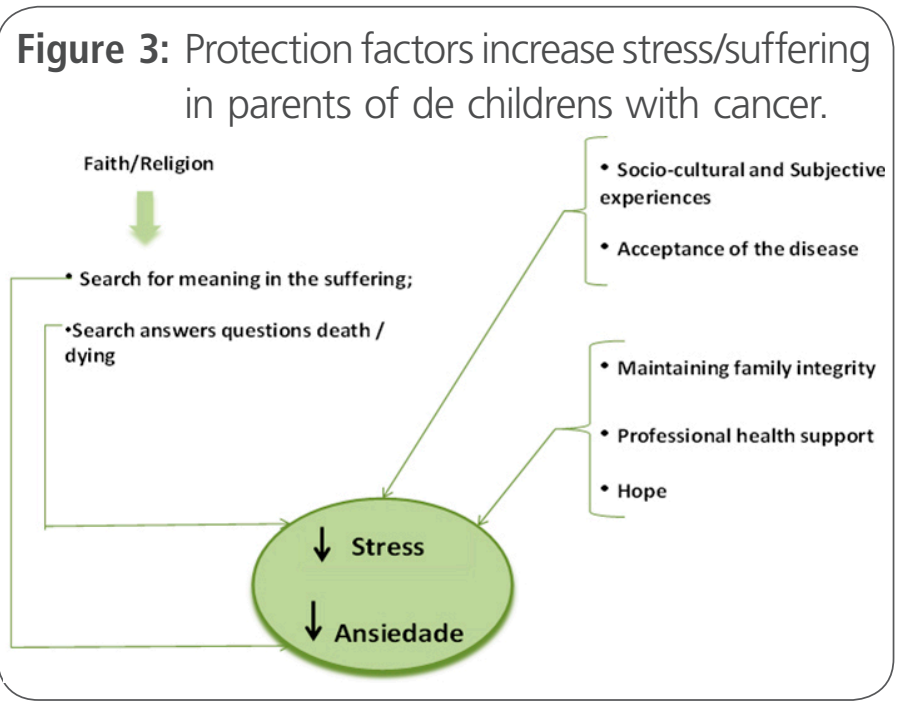

Parents learn how to rearrange time and their personal activities as the treatment progresses, reducing them, many times, to greater balancing and less permissive regarding the sick children. Learn to trust their children to others' care - intrinsic factor of most mothers -, besides learning that, despite the negative effects, chemotherapy is required [3]. The literature also highlights the secondary gains related to experiences with cancer improved eating habits, sleep quality and exercise [19].

\section{Interventions in relatives of pediatric oncology patients}

Regarding the main conclusions (Table 2) it is consensus that investments must be done in a multitasking team that is prepared to take care of a

Table 2. Impacts from the perspective of death in pediatric oncology patients. Main consideration of the authors.

\begin{tabular}{|l|l|l|}
\hline Journal & Sample & \multicolumn{1}{c|}{ Study Particularities } \\
\hline Sampaio [8] & 2011 & $\begin{array}{l}\text { To take care of the caregiver is task of the health professional, because to promote a } \\
\text { healthful caregiver has significant impacts in the patient health. }\end{array}$ \\
\hline Angelo [9] & 2010 & $\begin{array}{l}\text { The effect of the disease on patient and his/her family are multifaceted and reciprocal } \\
\text { affecting everyone. The family, due to the suffering, may try searching the meaning of } \\
\text { the existence by using the religion/faith as a instrument. New researches are necessary to } \\
\text { specify the beliefs and meanings of the suffering, besides turning possible the alleviating } \\
\text { of it. }\end{array}$
\end{tabular}




\begin{tabular}{c|l} 
Castro[10] 2010 & $\begin{array}{l}\text { To be Mother of a child with cancer is to live abrupt transformations in many feeling of } \\
\text { the existence. }\end{array}$ \\
$\begin{array}{c}\text { Deh, Collier } \\
\text { and } \\
\text { Hall[11] }\end{array} 2012$ & $\begin{array}{l}\text { Both, father and mother revealed level of stress greater that majority of the Jordanian } \\
\text { population. There are significant contributions of stress level of the fathers on the } \\
\text { mothers. There is necessity of psychological support to the parents of children with } \\
\text { cancer. }\end{array}$
\end{tabular}

Duarte, Zannini and Nedel[12]

\section{Eiser, Eiser} and

Stride [13]

Han, Cho and

$\operatorname{Kim}[6]$

2009

2005

2012

Each family is only and presents different dynamic of organization front to cancer experience, however the challenge of the health professional is to articulate these differences and insert them in the care, easing the daily hospitalization.

There was impairment of the quality of life of mothers and children in the months that happened the diagnosis. Mothers who reported low quality of life have also said that life quality of their children was low. It urges to continue with efforts to improve the quality of life of these, especially, in the months that succeed the diagnosis.

Kazak et al[14]

2005

The culture plays an important factor in the form to deal with a son with cancer, in mothers Korean mothers. Future studies should consider methods of confrontations culturally more accepted and how they connect themselves with the results.

Posttraumatic stress symptoms (PTSS) are common among parents of children in treatment with cancer currently. Information about PTSS are important for health professional assists family and patients, trying to normalize the traumatic situations; in the interventions that are appearing and that search to promote well-being.

Kolsdhorf and

Costa Jr.[3]

\section{Kolsdhorf} and

Costa Jr[15]

$$
\text { Malta, Schall }
$$
and

Modena [16]

Miedema et. al[17]

Moreira and Angelo [18]

Nehmy et. al[7]
2008

2008

The study deepens data already reported in the literature regarding the caregiver: learning about him, about the treatment and behavior patterns considered favorable among others. It detaches the importance of more psychosocial interventions in patients and caregivers.

Necessary to investigate of more specific and systematic form the difficulties which the caregivers and patients are subject during the treatment, in order to make possible more efficient strategies of psychosocial intervention.

The clarification on the diverse aspects of the illness allows elaboration better, by the caregivers, about this problem, contributing for a better experience of the childhood cancer and its treatment.

Economic questions appear as significant preoccupation at a delicate moment for the family. This economic load can have effect, in the long run, on the financial security, quality of life and future well-being of all the family, in particular the mother. Programs of financial assistance for families of seriously sick children need to be revised and to be extended.

There was connection between kinship and temporality, in which observes the formation of mother role in all its dimensions.

Cancer involves symbolic values about death, and that are most impactful on children The search of the leukemia diagnosis by the parents is an example of the crooked way that leads to a diagnosis said not "common" for children. 


\begin{abstract}
Oliveira, Costa and 2006 The dialogue lived intuitive and scientifically possible the mothers to receive cares that Nóbrega[19] promoted its well-being and to "be-good" in the best situation lived with their children. Also it made possible the reflection, conceptualization and description of a phenomenon that disclosed "be-with" and "make-with" of the nurse in a humanistic relation with mothers of children with cancer.
\end{abstract}

\begin{tabular}{|c|c|c|}
\hline Oliveira et. al[4] & 2010 & $\begin{array}{l}\text { Necessity to redirect the boarding to the mothers who follow her children to the } \\
\text { chemotherapy; recommended to look closely to mothers and their children, due to the } \\
\text { disease process to be joint. }\end{array}$ \\
\hline $\begin{array}{l}\text { Panganiban- } \\
\text { Corales and } \\
\text { Medina Jr [20] }\end{array}$ & 2008 & $\begin{array}{l}\text { Many Philippine families have inadequate economic resources and are moderately or very } \\
\text { unstructured. Many caregivers are exposed or are already experiencing great pressures. } \\
\text { To give the cares appropriated for these families, the doctors must regularly evaluate the } \\
\text { family function, resources and tension lived by the caregivers. Questionnaire SCREEM-RES } \\
\text { used in this study is a useful and trustworthy instrument to evaluate the adequacy of the } \\
\text { family resources. }\end{array}$ \\
\hline $\begin{array}{l}\text { Patiño-Fernadez et } \\
\quad \text { al[21] }\end{array}$ & 2008 & $\begin{array}{l}\text { Immediately after the diagnosis of cancer, many parents have symptoms of acute stress } \\
\text { (SAS), with a subsample demonstrating ASD (previous symptoms - Acute Stress Disorder). } \\
\text { Parents more anxious to have increased the risk of more intense reactions. The results } \\
\text { support the necessity for psychosocial support at diagnosis and throughout treatment to } \\
\text { families who are at risk for stress reactions / distress. }\end{array}$ \\
\hline Pritctard et. al[22] & 2009 & $\begin{array}{l}\text { Parents of children with terminal cancer may notice when their son's death will be occur } \\
\text { very differently: some are surprised, while others feel that they waited too long to release } \\
\text { their son from suffering. Doctors can use these descriptions and patterns symptoms of } \\
\text { associated to help families prepare for the last week of their son and the last day. }\end{array}$ \\
\hline Quintana et. al[23] & 2011 & $\begin{array}{l}\text { Emerging feelings of helplessness and guilt overloading the primary caregiver, making this } \\
\text { feel helpless, culminating in feelings of helplessness. }\end{array}$ \\
\hline $\begin{array}{l}\text { Rajajee, Ezhilarasi } \\
\text { and Indumathi [24] }\end{array}$ & 2007 & $\begin{array}{l}\text { The familiar structure is the mainstay for the psychological and emotional security. } \\
\text { Support by a group of well-prepared professionals would improve this familiar mainstay. }\end{array}$ \\
\hline Silva et. al.[1] & 2009 & $\begin{array}{l}\text { Assistance, based on the humanization of health professionals (emphasis on nursing) is of } \\
\text { paramount importance in the treatment of the pediatric oncology patient and their family. }\end{array}$ \\
\hline
\end{tabular}

sick person, as well as of those who surround the patient. The mother, who in most cases is the main caregiver, deserves special attention in the negotiations between the binomial life/death, as well as special attention should be given to the consequences of the children situational [10].

Spiritual interventions such as listening, being present, provide hope, give direction has been termed as thoughtful responses, which are the basis for the spiritual care [9]. Han, Cho, Kim [6] highlighted eight of the top ten coping strategies that Korean mothers perceived as being most helpful were rela- ted to coping pattern I: maintaining family integration and an optimistic definition of the situation.

The investigations indicate that the acceptance of the disease by parents is performed more easily when they begin to understand more about the disease and its reverberations [15]. They also describe this kind of information as contributing to their subsequent well-being as bereaved parents [22]. It is observed also in the literature that parents have a perception of some symptoms that are preludes son death. However, these perceptions are not homogeneous, Pritchard et al., [22] report the expec- 
ted death as: anticipated, evident or awaited for some time. Therefore, try to resolve the doubts of parents is an important part of the health team work. Group therapy was useful for sharing emotional trauma and exchanging day to day problems of childcare in Indian study [24].

Observed the presence of small samples [3, 4, $7-10,12,15-18,19,22]$ that point out the importance of assessing the consistency of results. Another limitation: only one study presents a comparative analysis [11]. Although some authors report that these peculiarities do not affect the results, the reproducibility as well as the generalization may be harmed.

\section{Conclusion}

Therefore, it is important to mention the presence of common features that families experience from diagnosis to death of a pediatric oncology patient. By the latest research are evident: family breakdown[1, 23, 24]; maternal stress levels much higher than paternal $[4,12,13,21]$; adding new knowledge and behaviors regarding treatment disease [3, 10, 15]; mother as primary caregiver; religiosity as a way of facing $[1,9,12,16]$; and costs expended during the illness and implications [3, 15, 17, 20].

In this sense provide social support to the family members of children with cancer is a part of integral medical care delivery. Attention to family members, monitoring the developments of intrafamily relation, the counseling by the health professional are essential on own positive development of the patient. It is extremely important a healthcare team integrated, updated and holistic fairly accurate. Thus, acknowledge the clients' support needs is important to plan medical care and guide research development, whose results can be used in clinical practice.

\section{Acknowledgments}

We are grateful to the Scientific Writing Lab (LA$\mathrm{BESCl}$ ) - Faculty of Medicine, Federal University of Cariri (UFCA).

\section{Conflict of interest}

The authors declare no conflicting of interest.

\section{Role of the funding source}

We have no fundation source. 


\section{References}

1. Silva FAC, Andrade PR, Barbosa TR, Hoffmann MV, Macedo $C R$. Representation of the getting sick process of children and teenagers with oncologic diseases together with family. Esc. Anna Nery.2009; 13(2): 334-341.

2. Siegel R, Naishad HD, Jemal A. American Cancer Society. Cancer Statistics 2012. CA: CA-Cancer J. Clin.2012; 62(1): 1029. Available: http://www.cancer.org/acs/groups/content/@ epidemiologysurveilance/documents/document/acspc-031941. pdf

3. Kohldorf M, Costa Jr AL. Caregivers of children with leukemia: treatment demands and learning related to new behaviors. Estud. psicol.2011 16(3): 227-234. Available: http://www.scielo. br/scielo. php? pid=S1413-294X2011000300004\&script=sci_ arttext

4. Oliveira RR, Santos LF, Marinho KC, Cordeiro JABL, Selge AKM, Siqueira KM. Ser mãe de um filho com câncer em tratamento quimioterápico: uma análise fenomenológica. Cienc. Cuid Saúde. 2011; 9(2): 374-382. Available: http://periodicos.uem.br/ ojs/index.php/CiencCuidSaude/article/viewFile/11250/6089

5. Brasil. Instituto Nacional da Criança com câncer (INCA). Incidência de Câncer no Brasil - Estimativa 2014. Rio de Janeiro, 2014. Available: http://www.inca.gov.br/estimativa/2014/ sintese-de-resultados-comentarios.asp

6. Han HR, Cho EJ, Kim D, Kim J. The report of coping strategies and psychosocial adjustment in Korean mothers of children with cancer. Psychooncology.2009; 18(9): 956-964. Available: http:// www.ncbi.nlm.nih.gov/pmc/articles/PMC3056775/

7. Nehmy RMQ, Britto AC, Mota JAC, Oliveira BM. The parents' perspective on receiving a diagnosis of acute lymphoid leukemia in children and adolescents: a Brazilian experiment. Rev. Bras. Saud. Matern. Infantil. 2011; 11(3): 293-299. Available: http://www.scielo.br/scielo.php?script=sci_arttext\&pid $=$ S1519-38292011000300010

8. Sampaio AS .Taking care of the caregiver: Perspective of psychological performance in a specific support house. Psicol. Argum. 2011; 29(67): 491-498. Available: http://www2.pucpr. $\mathrm{br} / \mathrm{reol} / \mathrm{index} . \mathrm{php} / \mathrm{pa}$ ?dd1=5794\&dd99=view

9. Angelo M. Hearing the voice of the family: narratives about suffering and spirituality. Mundo Saúde. 2010; 34(4): 437443. Available: http://www.saocamilo-sp.br/pdf/mundo_ saude/79/437a443.pdf

10. Castro EHB. A experiência do câncer infantil: repercussões familiares, pessoais e sociais. Rev. Mal-Estar Subj.2010; 10(3): 971-994. Available: http://pepsic.bvsalud.org/scielo. php?script=sci_arttext\&pid=\$1518-61482010000300013
11. Deh RM, Collier J, Hall C. Parental stress when caring for a child with cancer in Jordan: a cross-sectional survey. Health Qual Life Outcomes. 2012; 10(88): 2-7. Available: http://www.ncbi.nlm. nih.gov/pmc/articles/PMC3416682/

12. Duarte MLC, Zanini LN, Nedel MNB. O cotidiano dos pais de crianças com câncer e hospitalizadas. Rev. Gaúc. Enf. 2012; 33(3): 111-118. Available: http://seer.ufrgs.br/ RevistaGauchadeEnfermagem/article/view/21342/21953

13. Eiser C, Eiser JR,Stride C.B. Quality of life in children newly diagnosed with cancer and their mothers. Health Health Qual Life Outcomes.2005; 3(29): s.p. Available: http://www.hqlo. com/content/3/1/29.

14. Kazak AE, Boeving CA, Alderfer MA, Hwang WT, Reilly A. Posttraumatic Stress Symptoms During Treatment in Parents of Children With Cancer. J Clin Oncol. 2005; 23(30): 7405-7410. Available: http://jco.ascopubs.org/content/23/30/7405.full.pdf

15. Kohldorf M, Costa Jr AL. Dificuldades Relatadas por Cuidadores de Crianças e Adolescentes com Leucemia: Alterações comportamentais e familiares. Interação em Psicol. 2010; 14(1): 1-12. Available: http://ojs.c3sl.ufpr.br/ojs/index.php/psicologia/ article/viewFile/15320/12787

16. Malta JDS, Schall VT, Modena CM. Pediatric cancer: under the look of th family/caregivers. Psicol em Pediatr. LILACS. Base de dados em saúde. 2008. [Acessed in 19th December, 2014]. Available: http://cto.verticce.com/livros/pediatria_ moderna_2008_n3/content. 114-118.

17. Miedema B, Easley J, Fortin P, Hamilton R, Mathews M. The economic impact on families when a child is diagnosed with cancer. Medical Oncology. Current Oncol. 2008; 15(4): sp. Available: http://www.ncbi.nlm.nih.gov/pmc/articles/ PMC2528308/

18. Moreira PL, Angelo M. Becoming a mother of a child with cancer: building motherhood. Rev. Latino-Am. Enfermagem.2008; 16(3):355-61. Available: http://www.scielo.br/pdf/rlae/ v16n3/04.pdf

19. Oliveira NFS, Costa SFG, Nóbrega MML. Lived dialogue between nurse and mothers of children with cancer. Revista Eletrônica de Enfermagem. 2006; 08(1): 99 - 107.Available: http://www.fen. ufg.br/fen_revista/revista8_1/pdf/v8n1a14.pdf 


\section{INTERNATIONAL ARCHIVES OF MEDICINE

Vol. 8 No. 30 doi: $10.3823 / 1629$
20. Panganiban-Corales AT, Medina Jr MF. Family resources study: part 1: family resources, family function and caregiver strain in childhood cancer. Asia Pac Fam Med.2011; 31; 10(1): 14. Available: http://www.ncbi.nlm.nih.gov/pmc/articles/ PMC3233495/

21. Patiño-Fernandes AM, Pai ALH, Alderfer $M$, Hwang WT, Reilly A, Kazak AE. Acute Stress in Parents of Children Newly Diagnosed With Cancer. Pediatr Blood Cancer.2008; 50(2): 289-292. Available: http://www.ncbi.nlm.nih.gov/pmc/articles/ PMC2811161/

22. Pritchard M, Srivastava DK, Okuma JO, Powell B, Burghen E, West NK et al. Bereaved Parents' Perceptions About When Their Child's Cancer-Related Death Would Occur. J Pain Symptom Manage. 2009; 38(4): 561-567. Available: http://www.ncbi.nlm. nih.gov/pmc/articles/PMC2941143/

23. Quintana AM, Wottrich SH, Camargo VP,Cherrer EQ, Ries PK. Mournings and struggles: Family reestructuring following cancer in a child/adolescent. Psicol. Argum.2011; 29(65): 143-154. Available: http://www2.pucpr.br/reol/index.php/ PA?dd1 $=4594 \& d d 99=p d f$

24. Rajajee S, Ezhilarasi S, Indumathi D. Psychosocial problems in families of children with cancer. Indian J Pediatr. 2007; 74(9): 837-

9. Available: http://www.ncbi.nlm.nih.gov/pubmed/17901670

\section{Comment on this article:}

\section{$4[$ in $8+\boldsymbol{S} P$}

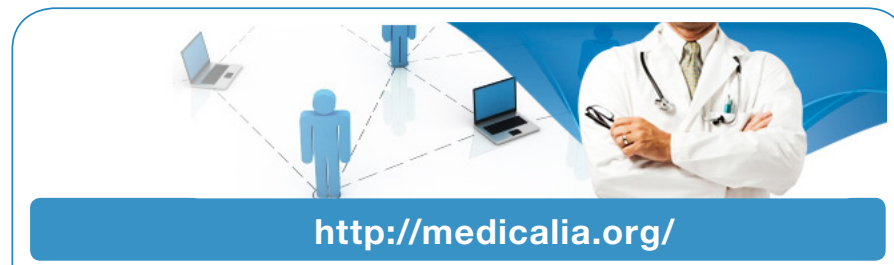

Where Doctors exchange clinical experiences, review their cases and share clinical knowledge. You can also access lots of medical publications for free. Join Now!

\section{Publish with iMedPub}

http://www.imed.pub

International Archives of Medicine is an open access journal publishing articles encompassing all aspects of medical science and clinical practice. IAM is considered a megajournal with independent sections on all areas of medicine. IAM is a really international journal with authors and board members from all around the world. The journal is widely indexed and classified Q1 in category Medicine. 